\title{
INTERNATIONAL PEACE INITIATIVES TO RESOLVE THE CONFLICT IN SYRIA
}

\author{
Vasil Stankov \\ Ph.D., National Defense College, Sofia, Bulgaria, vassilst@abv.bg
}

\begin{abstract}
The article "International peace initiatives to resolve the conflict in Syria" reveals the international efforts to bring the conflict to an end and start a meaningful peace process that would reconcile the conflicting parties and engage them in a series of negotiations aiming to initiate a National Dialogue, draft a mutually acceptable Constitution and prepare free and fair elections that would decide the issue of political power in the country. The article outlines the peace endeavors of the United Nations Security Council, which adopted several resolutions to support the efforts to prevent the use of chemical weapons in Syria, authorize a mechanism to conduct humanitarian operations and establish cease-fire conditions. Furthermore, the article describes in detail the so called Geneva Peace Process as the framework, which started negotiating the establishment of transitional power architecture with a transitional governing body possessing full executive powers, comprised of representatives of the Syrian regime and the opposition. The article goes on to highlight the guidelines and principles of the political transition and the results of the subsequent rounds of political talks, which didn't yield a conclusive outcome because of the unfavorable conditions on the ground and the ongoing offensive of the government forces against the opposition groups. Then, the article analyzes the peace efforts undertaken under the leadership of the countries engaged to the greatest extent with the events on the ground - Russia, Turkey and Iran, and summarizes the results achieved at the meetings held in Astana in order to negotiate conditions for the cessation of military operations and the launch of a peace dialogue between the regime and the opposition. The article emphasizes upon the meeting of 3-4 May 2017, when a memorandum was signed on creating four De-escalation Zones in the territories controlled by the opposition, and underlines the importance of the next meeting, when decisions were made to establish a trilateral coordination centre for combined operations in the zones and to convene a Syrian Congress of the National Dialogue in January 2018 in Sochi. Finally, the article concludes that the political settlement requires a balance between the geopolitical objectives of the outside factors involved and the power ambitions of the internal players and argues that the outcome of the negotiations depends mainly on the situation on the ground.
\end{abstract}

Keywords: conflict, Syria, negotiations, peace process.

\section{INTRODUCTION}

The civil war in Syria is an internal conflict with far-reaching effects on the security in the Middle East and neighbouring regions, as well as in Europe and the world as a whole. From its onset onwards, the conflict has had multiple negative implications on the security environment regionally and globally. The destabilizing impact of the conflict on the security environment in the Middle East and neighbouring regions reaches critical levels, thus triggering an increasing joint endeavour to take feasible measures for its settlement. This is because the Syrian conflict shapes the security environment both regionally and globally, producing 
security challenges and threats simultaneously with the changing strategic paradigm in the Black Sea zone and the growing military activity in the Black Sea region. Russia's direct military intervention in the Syrian conflict was another step of widening Russian influence to the East and eventually to secure its access to the Mediterranean. However, the ongoing militarization of the Black Sea is non-productive, as it leads to higher security risks.

The main challenge throughout Syrian peace negotiations is the need to tackle differences among stakeholders which have diverse and often diametrically opposed interests. The prospects for a successful outcome depend on the ability to design mechanisms addressing the controversies of the participants in the conflict and to negotiate mutually beneficial conditions to engage them in the peace process. The attempts to initiate a transitional political period aimed at conciliation and power sharing between the opposing sides should be in line with the balance of interests and military operations on the ground. Direct and indirect players in the Syrian conflict are aware that peace will be a function of the war, i.e. negotiations will depend directly on the outcomes of military operations. Therefore the opposing sides first seek to achieve military success that would warrant them favourable starting positions in the peace process.

\section{THE SYRIAN PEACE PROCESS}

The UN has been more actively engaged with the conflict after the failed peace plan of the Arab League, which envisaged a mission of observers to be sent to monitor the implementation of the measures intended to reduce tensions. Given the uncontrolled escalation of clashes and hostilities in January 2012, the Arab League terminated the mission for an indefinite time, which marked the end of the regional attempts to resolve the conflict.

A positive example of the effective and efficient work of the UNSC is Resolution 2118 of 27.09.2013, supporting the joint plan of the United States and Russia on destruction and elimination of the stockpile of chemical weapons in Syria. The resolution states that "no party should use, develop, produce, acquire, stockpile, retain, or transfer chemical weapons" and that the other countries "shall refrain from providing any form of support to non-state actors that attempt to develop, acquire, manufacture, possess, transport, transfer or use weapons of mass destruction, including chemical weapons, and their means of delivery". The plan has been relatively successful since 2014 but after the investigation of the UN and the Organisation for the Prohibition of Chemical Weapons (OPCW) revealed the use of chemical weapons by the regime, Russia has gradually withdrawn its support and in 2017 the investigation came to an end.

In July 2014 the UNSC adopted Resolution 2165, authorizing the UN to deliver humanitarian aid without prior permission from the Syrian authorities and establishing a mechanism to conduct humanitarian operations. In February 2018 Resolution 2401 was adopted, establishing a 30-day cessation of hostilities between the warring parties across the Syrian territory. The humanitarian break was necessary to deliver aid and evacuate the critically sick and wounded.

The Geneva Peace Process starts from the so-called Geneva Communique or Geneva-1, signed on 30 June 2012 by the members of the Syria Action Group - the Secretaries-General of the United Nations and the Arab League, the European Union High Representative for Foreign and Security Policy, the foreign ministers of UNSC permanent member states, and the foreign ministers of Turkey, Iraq, Kuwait and Qatar. The importance of this document lies in the fact that it provides for the establishment of "a transitional government with a transitional governing body possessing full executive powers", comprised of representatives of the Syrian regime and the opposition. The document lays down the guidelines and principles of the political transition as follows:

- The transition should be led by the Syrians themselves and should offer a perspective for the future that can be shared by all in Syria;

- The transition period should include a time-table with clear steps towards the realization of that perspective;

- All actions should be taken in an environment of safety for all, stability and calm;

- The results should be valid for all and should be reached rapidly without further bloodshed.

For the first time specific actions to be implemented during the transition were defined:

- National Dialogue process should start and all groups and segments of the society in Syria must be enabled to participate in it;

- The constitutional order and the legal system should be reviewed and the constitutional draft should be subject to popular approval; 
- Once the new constitutional order is established, it is necessary to prepare for and conduct free and fair multi-party elections for the new institutions and offices that have been established with the new Constitution.

In January 2014 the second round of negotiations was held (so-called Geneva-2), which rapidly failed as there were no agreed criteria to define which groups belonged to the legitimate Syrian opposition.

In December 2015 the UNSC adopted Resolution 2254, thus reconfirming its endorsement of the Geneva Communiqué, approving the establishment of credible, inclusive and non-sectarian governance for six months and setting a schedule for holding elections within 18 months and a schedule for drafting a new constitution. These rather ambitious intentions were followed by many initiatives aimed at the formation of a united negotiation team to represent the entire Syrian opposition. This appeared to be an extremely difficult task, given the different goals and interests of the stakeholders.

The next round (Geneva-3) was held in February 2016 and lasted only two days without achieving any significant results. The negotiations were terminated because of the ongoing offensive of the government forces against the opposition groups in the area of Aleppo. In 2017 several rounds of negotiations (Geneva 4-8) were held but there was no result due to controversies on key issues such as the pertinence of negotiations before the collapse of the regime, the formula of power and the participation of Bashar al Assad in the post-conflict arrangements, the constitutional order of Syria after the war.

The efforts for political settlement continued but this time under the leadership of the countries engaged to the greatest extent with the events on the ground - Russia, Turkey and Iran.

From January to October 2017 seven international meetings were held in Astana, hosting negotiations aimed to create conditions for the cessation of military operations and the launch of a peace dialogue between the regime and the opposition. At the first meeting (23-24 January) aimed to specify the conditions for ceasefire, the US attended as observers, later joined by the UN (the Special Envoy Staffan de Mistura) and Jordan. The guarantor states (Russia, Iran and Turkey) agreed on establishing a trilateral mechanism of control on compliance with the ceasefire. At the next meetings they agreed on establishment of a joint working group (accountable to the UN) for monitoring the ceasefire regime and discussed issues for the maintenance of security in the regions joining the truce.

At the meeting of 3-4 May 2017 a memorandum was signed on creating four De-escalation Zones in the territories controlled by the opposition as follows: Zone 1 including parts of the provinces of Idlib, Latakia, Hama and Aleppo, Zone 2 in the province of Homs, Zone 3 in the suburb of Damascus, Eastern Ghouta, and Zone 4 including parts of the provinces of Daraa and Al Quneitra. The zones aim to negotiate on the spot conditions for ceasefire suspension, gradual disarmament and integration of armed groups, thus improving the humanitarian situation and creating favourable conditions for political settlement of the conflict. To confirm that the zones did not aim at Syria's divide the guarantor states signed a joint statement, indicating that they supported the preservation of Syria's sovereignty, independence, unity and territorial integrity. After that Zone 1 was conditionally transformed into a demilitarized zone (DMZ).

The main outcome of the next meetings was the agreement on the establishment of a trilateral coordination centre for combined operations in the de-escalation zones. Moreover, they agreed on the convocation of a Syrian Congress of the National Dialogue, to be held in January 2018 in Sochi with the participation of all segments of Syrian society (Baresh, 2019; Bekiarova, 2017; Bekiarova, 2019a; 2018-b).

The Congress took a decision to set up a committee to draft a new Constitution pursuant to Resolution 2254, triggering a process of negotiation of the post-war governance in Syria. At the next two meetings, possibilities for improving the dialogue between the regime and the opposition and return of the refugees and internally displaced persons were discussed and the guarantor states confirmed their commitment to assist in the formation of a Constitutional committee (Terziev, Petkov, Krastev, 2018c-k; Terziev, Bankov, Georgiev, 2018I-m).

\section{CONCLUSION}

The problems and stand-offs in South Caucasus reveal it as a miniature model of the world with all existing possible challenges, risks, and threats. It is difficult to find any positive signs of the end of confrontation. Options for settlement of the conflict have not been found yet. Probably the regulation of the conflict for Nagorno-Karabakh would continue for a lengthy period of time and the conflicts on Georgian territory would not be reversed and separatist territories would not be back to the country's territories.

In the foreseeable future, the existing status-quo in the relationships of the global geopolitical players would develop negatively and the confrontation would last for a long period. Russia is expected to make efforts to consolidate the near foreign areas included in the sphere of the exclusive Russian interests, which is clearly 
demonstrated by the annexation of Crimea, the conflicts in South East Ukraine and the whole Black Sea region. Such a policy does not lead to peacemaking and stability.

The US role in South Caucasus will depend on the situation in the Black Sea region, Central and South Asia and no increase of the US military and political presence is expected for the time being. Given the current developments in the Middle East, in Afghanistan and the unclear future of US-Iran relationships, a more proactive US policy in South Caucasus could be expected.

In the conditions of enhanced commitment by the big geopolitical players it may be expected that Georgia, Armenia and Azerbaijan will gradually realise their common interests and will seek to find paths to one another. This would be a clear sign of their ability to find a reasonable and peaceful solution to their common problems.

\section{REFERENCE LIST}

https://www.kavkaz-uzel.eu/articles/14833/, (2019).

http://cge.evrazia.org/geopolitics_10.shtml, (2019a),

Arutiunov, S.A. (2019b), Ethnicity in the Caucasus: Ethnic Relations and Quasi-Ethnic Conflicts. http://www.circassianworld.com/ethnicity.html.

http://old.iea.ras.ru/topic/census/mon/yunus_mon2001.htm, (2019c).

Markedonov, S. (2012). Defakto obrazovaniya postsovetskogo prostranstva: dvattsat let gosudarstvenogo stroitelystva. Institut Kavkaza, Erevan, 2012 s.48. (Markedonov, S. Дефракто образования постсоветского пространства: дватцат лет государственого строительства. Институт Кавказа, Ереван, 2012 с.48).

http://national-

mentalities.ru/diversity/nacionalnopsihologicheskie_osobennosti_etnosov_rossii/severnyj_kavkaz/serd yuk_yu_o_mentalitet_narodov_kavkaza/, (2019d).

Velichko.V.L. (2007). Caucasus Russian Affairs and Intertribal Problems. Baku, Vatan, 2007. p.12.

https://hdman.livejournal.com/67016.html, (2019e).

http://www.randevu-zip.narod.ru/caucase/caucase.htm, (2019f).

http://cge.evrazia.org/geopolitics_8.shtml, (2019g).

https://www.heritage.org/europe/commentary/turkeys-foreign-policy-plans-2009, (2019h).

http://www.karabakh.org/news/interviews/gerard-libaridian-it-is-quite-possible-for-azerbaijan-to-initiate-waragainst-armenia-p3/,(2019i).

Abasov, A. Hachatryan, A. (2002). Variantay resheniya karabahskogo konflikta: idei i realynosty. BAKU, 2002. (Abasov, A. Hachatryan, A. Варианты решения карабахского конфрликта: идеи и реальность. БАКУ, 2002).

Bekiarova, N. (2011). Gruziya i Rusiya mezhdu vrazhdata i politikata na "malkite stapki” po patya na dobrosasedstvoto, Georgia and Russia between animosity and the „small steps” policy along the path towards good neighbourhood, (Tri godini sled kraya na petdnevnata avgustovska voyna). Sp. Voenen Zhurnal, br. 1, 2011 g. s.67-78. (Bekiarova, N. Грузия и Русия между враждата и политиката на „малките стъпки" по пътя на добросъседството, Georgia and Russia between animosity and the „small steps" policy along the path towards good neighbourhood, (Три години след края на петдневната августовска война). Сп. Военен Журнал, бр. 1, 2011 г. с.67-78.).

https://www.panorama.am/ru/news/2011/12/01/akhlevdiani/847542, (2019j).

http://radiovesti.ru/news/category/all/22-04-2019/, (2019k).

Kanchev, R. (2008). Zashto Rusiya ne sledva zapadniya model na demokratsiyata? Why Russia does not follow the Western model of democracy?, UI Sv. Kliment Ohridski, 2008, s.173 (Kanchev, R. Защо Русия не следва западния модел на демокрацията? Why Russia does not follow the Western model of democracy?, УИ Св. Климент Охридски, 2008, с.173). 
https://geopolitica.eu/2004/1175, (2019l).

Stankov, V. (2019m). Siriyskiyat konflikt i vazmozhnite stsenarii za postigane na stabilnost i mir. Sp. Voenen zhurnal, br. 1-2, 2019. str. 19-20. ISSN 0861 -7392. (Станков, В. Сирийският конфрликт и възможните сценарии за постигане на стабилност и мир. Сп. Военен журнал, бр. 1-2, 2019. стр. 19-20. ISSN 0861 -7392).

https://report.az/en/incident/john-bolton-azerbaijan-is-a-strategically-important-country-for-us/, (2019n).

https://www.24chasa.bg/novini/article/6874844, (2019o).

https://news.bg/world/stoltenberg-gruziya-shte-se-prisaedini-kam-nato-rusiya-nishto-ne-mozhe-danapravi.html, (2019p).

Armencheva, I., N., Bekiarova, I., Ivanov. (2019q). Cyber globalization as an in/stability factor. Proceedings of INTCESS 2019-6th international conference on education and social sciences, 4-6 february 2019Dubai, U.A.E. ISBN: 978-605-82433-5-4.

Armencheva, I., Smolenov, S. (2015). From Real Cyber Conflict through Wishful Cyber Security to (un) Likely Cyber Peace, Revista Academiei Fortelor Terestre NR. 3 (79) /2015, p. 260, 2015.

Armencheva, llina. (2015a). Aspects of Policies and Strategies for Cyber security in EU. Journal of Defense Resources Management, 6, 2015, 2, pp. 37-44.

Bekiarova, N. Armencheva, I. (2019r). Is the Peaceful Regulation of the Nagorno-Karabakh Conflict Mission Possible? Proceedings of INTCESS 2019-6th International Conference on Education and Social Sciences, 4-6 February 2019- Dubai, U.A.E. ISBN: 978-605-82433-5-4.

Bonev, R. (2018). Epistemologicheskiyat anarhizam na Pol Fayerabend i geopoliticheskoto modelirane na strategicheskata sreda za sigurnost prez hhi vek. opit za istoriografski pregled. // Voenna akademiya "Georgi Stoykov Rakovski" - 105 godini znanie v interes na sigurnostta i otbranata. Sbornik dokladi ot Mezhdunarodna nauchna konferentsiya 6 - 7 april 2017 g., Sofiya, Voenna akademiya „Georgi Stoykov Rakovski“", 2018, ISBN 978-619-7478-00-6, s. 79-85 (Бонев, Р. Епистемологическият анархизъм на Пол Файерабенд и геополитическото моделиране на стратегическата среда за сигурност през ххі век. опит за историографски преглед. // Военна академия „Георги Стойков Раковски" - 105 години знание в интерес на сигурността и отбраната. Сборник доклади от Международна научна конференция 6 - 7 април 2017 г., София, Военна академия „Георги Стойков Раковски“, 2018, ISBN 978-619-7478-00-6, с. 79-85).

Bonev, R. (2017). Koordinatay vneshnepoliticheskoy strategii gosudarstva $v$ teorii mezhdunarodnayh otnosheniy. Savremenni predizvikatelstva pred sigurnostta. Sbornik dokladi ot godishna nauchna konferentsiya na fakultet "Natsionalna sigurnost i otbrana“ na VA“G.S.Rakovski“ 19-20.05.2016, Vtora chast. S., 2017, ISBN978-954-9348-89-7, s. 91-99 (Бонев, Р.Координаты внешнеполитической стратегии государства в теории международных отношений. Съвременни предизвикателства пред сигурността. Сборник доклади от годишна научна конференция на фракултет „Национална сигурност и отбрана“ на ВА“Г.С.Раковски“ 19-20.05.2016, Втора част. С., 2017, ISBN978-9549348-89-7, с. 91-99).

Kalinov,T. (2018a). Relationships between command, management, and communications. To continue in different directions or to remain in same field? Knowledge - International Journal Scientific Papers, vol. 28.6 (December, 2018). ISSN 2545-4439 (printed version), 1857-923X (e-version).

Stankov, V. (2018b). Kam vaprosa za vliyanieto na siriyskata kriza varhu regionalnata ne/sigurnost /. Godishna voennonauchna konferentsiya s mezhdunarodno uchastie na tema,,Savremenni aspekti na sigurnostta - predizvikatelstva, podhodi, resheniya"20 - 21 yuni 2018. Godishnik na Voenna akademiya „G. S. Rakovski“fakultet „Komandno-shtaben“, 2018. ISSN 1312-2991 (Станков, В. Към въпроса за влиянието на сирийската криза върху регионалната не/сигурност /. Годишна военнонаучна конференция с международно участие на тема,Съвременни аспекти на сигурността - предизвикателства, подходи, решения" 20 - 21 юни 2018. Годишник на Военна академия „Г. С. Раковски“фракултет „Командно-щабен“, 2018. ISSN 1312-2991).

Stankov, V (2014). Partiyata na spravedlivostta i razvitieto i savremennata politika za sigurnost i otbrana na Turtsiya, Spisanie „Voenen zhurnal”, 2014/4, str. 77-86, ISSN 0861 -7392. (Станков, В Партията на справедливостта и развитието и съвременната политика за сигурност и отбрана на Турция, Списание „Военен журнал”, 2014/4, стр. 77-86, ISSN 0861 -7392).

Terziev, V., Petkov, M., Krastev, D. (2018c). Operative mode for police cooperation between the member 
IJASOS- International E-Journal of Advances in Social Sciences, Vol. V, Issue 14, August 2019

states of the European Union. // Proceedings of SOCIOINT 2018- 5th International Conference on Education, Social Sciences and Humanities, 2-4 July 2018- Dubai, U.A.E, International Organization Center of Academic Research, www.ocerints.org, pp.473-476, ISBN: 978-605-82433-3-0.

Terziev, V., Petkov, M., Krastev, D. (2018d). European arrest warrant: appearance and preferences for fulfillment. // Proceedings of SOCIOINT 2018-5th International Conference on Education, Social Sciences and Humanities, 2-4 July 2018- Dubai, U.A.E, International Organization Center of Academic Research, www.ocerints.org, pp. 477-481, ISBN: 978-605-82433-3-0.

Terziev, V., Petkov, M., Krastev, D. (2018e). Eurojust casework on mafia-type criminal organisations. // Proceedings of SOCIOINT 2018- 5th International Conference on Education, Social Sciences and Humanities, 2-4 July 2018- Dubai, U.A.E, International Organization Center of Academic Research, www.ocerints.org, pp.487-491, ISBN: 978-605-82433-3-0.

Terziev, V., Petkov, M., Krastev, D. (2018f). Concept of joint investigation teams. // Proceedings of SOCIOINT 2018- 5th International Conference on Education, Social Sciences and Humanities, 2-4 July 2018- Dubai, U.A.E, International Organization Center of Academic Research, www.ocerints.org, pp.492-496, ISBN: 978-605-82433-3-0.

Terziev, V., Petkov, M., Krastev, D. (2018f). European arrest warrant and human rights of the accused. // Proceedings of SOCIOINT 2018- 5th International Conference on Education, Social Sciences and Humanities, 2-4 July 2018- Dubai, U.A.E, International Organization Center of Academic Research, www.ocerints.org, pp.501-504, ISBN: 978-605-82433-3-0.

Terziev, V., Petkov, M., Krastev, D. (2018g). Pumps for the action on the European Union in the scope of the European agenda on security. // Proceedings of SOCIOINT 2018- ${ }^{\text {th }}$ International Conference on Education, Social Sciences and Humanities, 2-4 July 2018- Dubai, U.A.E, International Organization Center of Academic Research, www.ocerints.org, pp.497- 500, ISBN: 978-605-82433-3-0.

Terziev, V., Petkov, M., Krastev, D. (2018h). The process of forming a criminal policy of the European Union. // Proceedings of SOCIOINT 2018- 5th International Conference on Education, Social Sciences and Humanities, 2-4 July 2018- Dubai, U.A.E, International Organization Center of Academic Research, www.ocerints.org, pp.505-510, ISBN: 978-605-82433-3-0.

Terziev, V., Petkov, M., Krastev, D. (2018i). Organization on the European Union in the sphere of penal preparation. // Proceedings of SOCIOINT 2018-5th International Conference on Education, Social Sciences and Humanities, 2-4 July 2018- Dubai, U.A.E, International Organization Center of Academic Research, www.ocerints.org, pp.482-486, ISBN: 978-605-82433-3-0.

Terziev, V., Petkov, M., Krastev, D. (2018j). Sources of European Union law. // Proceedings of SOCIOINT 2018- 5th International Conference on Education, Social Sciences and Humanities, 2-4 July 2018Dubai, U.A.E, International Organization Center of Academic Research, www.ocerints.org, pp.511516, ISBN: 978-605-82433-3-0.

Terziev, V., Petkov, M., Krastev, D. (2018k). The „Source of law“ category. // Proceedings of SOCIOINT 2018- 5th International Conference on Education, Social Sciences and Humanities, 2-4 July 2018Dubai, U.A.E, International Organization Center of Academic Research, www.ocerints.org, pp.517521, ISBN: 978-605-82433-3-0.

Terziev, V., Bankov, S., Georgiev, M. (2018I). The Change in the approach of the court of justice of the European Union in the context of market freedoms and internal situations. // Journal of Innovations and Sustainability, Plovdiv, Bulgaria, 4, 2018, 3, pp. 85-112, ISSN 2367-8127 (CD-ROM), ISSN 23678151 (on-line).

Terziev, V., Bankov, S., Georgiev, M. (2018m). The Stability and growth pact: pursuing sound public finances and coordinating fiscal policies in the EU member states. // Journal of Innovations and Sustainability, Plovdiv, Bulgaria, 4, 2018, 3, pp. 53-68, ISSN 2367-8127 (CD-ROM), ISSN 2367-8151 (on-line). 